\title{
新时期装饰装修工程管理措施探究
}

陈波

泰州市绿色建筑与科技发展中心

DOI:10.32629/btr.v3i5.3130

[摘 要] 建筑装饰装修工程在建筑工程中发挥了十分重要的作用, 工程的施工质量与建筑的使用功能有着十分密切的联系, 同时也直接关系 到建筑的舒适性。建筑装饰装修工程涵盖的内容较多, 极易受到多种因素的影响, 建筑单位需高度重视装饰装修工程管理工作,切实保障工程 的质量。

[关键词] 建筑装饰装修; 管理措施; 使用功能

建筑装饰装修工程施工中, 若质量不达标, 则会直接威胁工程的安全 性。因此, 应积极整改装修在装饰工程, 严格把控工程施工管理, 减少建筑 装饰装修工程中的影响因素, 更好的服务于大众的日常生活。

\section{1 建筑装饰装修工程施工的特点}

1. 1 工期较短

建筑装饰工程的工期较建设工程项目工期短。现阶段, 装饰装修行业 的竞争压力明显增大, 市场对工程装饰装修的要求也有所提高, 建筑施工 与装修工程需交替进行, 这就要求施工单位科学规划施工时间, 注重工程 的施工质量。

\section{2 工种多, 范围广}

建筑装饰施工中, 为改善装饰装修水平, 工程施工期间要明确分工, 在 出现工程问题时, 需积极组织不同的施工单位, 严格按照规范要求施工, 促 进工程的有序开展。

1. 3环境复杂

现阶段, 装饰装修工程施工与土建施工需交替进行, 施工人员需要轮 流施工, 这也增大了工程施工的难度, 在场工人要合理把控工程的施工顺 序。另外, 建筑建设完成后, 还要协调工程周边的环境和建筑装饰装修工程 施工的关系。

\section{4 建材种类较多}

我国科学技术日益完善, 出现了多种新型的装饰装修材料, 材料的类 型及样式也更加丰富, 在工程建设和施工中, 能够更加灵活地选择施工材 料。在选择施工材料的过程中, 一方面要高度关注材料的美观性, 另一方面 也需参照工程实际需求, 选择符合参数标准的施工材料。

在人行道建设过程中, 通过采取无障碍设计方法, 能够有效保障残疾 人士出行安全, 提高残疾人士出行效率。对于下肢残疾的人群来说, 在行走 过程中十分不便, 在涉及下肢残疾人群无障碍通道过程中, 应该适当提高 人生道路平坦度, 不会出现铁丝等障碍物。在铺设井盖过程中, 需要与地面 平行, 不可使用篦式井盖, 更不要随意设置垃圾桶等障碍物, 在地面设计中 采用防滑措施。对于视力残疾人群来说, 因为看不清问题, 所以对残疾人群 进行无障碍道路设计过程中, 应该保证悬挂物和凹凸高度大于 $220 \mathrm{~cm}$, 无障 碍通道通常不设置在人行道路中央位置, 而是设置在靠近建筑物的一旁, 无障碍道路宽度一般设定在 $50 \mathrm{~cm}$ 左右, 颜色为中黄色。

\section{5 结束语}

总而言之, 在城市道路建设与发展中无障碍设计作为重要内容, 在其 中发挥着重要作用, 相关部门在无障碍设计中, 按照以人为本设计要求, 并 且把无障碍设计理念运用到城市道路设计活动中, 提高城市道路出现质量, 促进城市更好发展。

\section{2 建筑装饰装修工程管理存在的问题}

2.1建筑装饰装修工程管理不规范

各个行业都有特定的管理制度, 对于建筑装饰装修工程行业也不例 外。建筑装饰装修企业往往会借助制定内部管理制度的方式, 对装饰装修 工程的各个环节实行管理, 确保工程高质量完工。然而, 多数建筑装饰装修 企业未能顺应社会发展趋势, 制定完善的内部管理制度, 这极大的制约 了企业的良好发展。由于我国建筑装饰装修行业的发展起点不同, 为此, 统一行业内部管理难度较大。而这也使建筑装饰装修工程中出现各种各 样的问题。

从装饰装修材料角度来说, 装饰装修材料是建筑装饰装修工程的重要 组成内容, 只有确保装饰装修材料质量符合标准要求, 才能保障整体装饰 装修工程质量。如果建筑装饰装修企业为节约投资成本, 选用劣质的装饰 装修材料, 不仅会降低整体工程质量, 还会对企业的公众信誉造成的损害, 进而制约企业的良好发展。

2.2 建筑装饰装修工程管理不到位

随着人们物质文化生活水平的不断提高, 建筑装饰装修行业的发展也 取得了长足的进步。同时, 越来越多的工艺、技术与设备应用到建筑装饰 装修工程中。然而工程管理不到位, 降低了工艺、技术与设备的应用水平, 限制了整个行业的良好发展。

此外, 部分管理人员责任意识淡薄, 工作态度松解, 所掌握的建筑装饰 装修专业知识不足, 在管理过程中出现各种各样的问题, 不仅增大了工程 质量安全隐患, 也直接影响了业主的居住舒适度。久而久之, 必定会导致建 筑装饰装修企业丧失市场竞争力, 甚至被主体市场边缘化。

\section{[参考文献]}

[1]郭棠.无障碍设计在市政道路设计中的体现分析[J].住宅与房地 产,2020,(09):97.

[2]许百江.无障碍设计在市政道路设计中的体现分析[J].科技经济导 刊,2018,26(30):98.

[3]杨格欧,王朝宁.无障碍设计在市政道路设计中的体现[J].建材与装 饰,2018,(03):102.

[4]陈华.市政道路设计中无障碍设计的分析 [J]. 绿色环保建 材,2018,(08):80+82.

[5]张朋.浅谈市政道路无障碍设计的实际应用[J].城市建设理论研究 (电子版),2018,(29):149.

[6]刘思博.论无障碍设计在市政道路设计中的体现[J].居舍,2019,(31):102.

[7]戴宇.市政道路设计中无障碍设计的体现研究 [J]. 建材与装 饰,2018,(35):268-269. 
2. 3建筑装饰装修工程安全防范意识淡薄

对于建筑装饰装修工程而言, 保证人身安全是第一要义, 且维护工程 安全性也是建筑装饰装修企业实现经济效益最大化的重要途径。然而, 部 分建筑装饰装修企业对工程安全缺乏重视, 不仅影响了施工效率、施工进 度与施工质量, 也给企业造成了不必要的经济损失。在现有的资金条件下, 部分企业为节约投资成本, 往往会采取偷工减料的方式, 加大了装饰装修 工程的安全隐患。

\section{3 提高建筑装饰装修工程管理水平的策略}

3. 1 确立绿色、安全工程项目管理目标

在建筑装饰装修设计与施工过程中, 要确立绿色、安全工程项目管理 目标, 充分考虑工程的功能性、舒适性与美观性需求。在绿色、安全施工 的前提下, 实现建筑装饰装修工程管理经济效益、社会效益与生态效益最 大化的目标。

3. 2优化装饰装修工程方案设计

要想确定建筑装饰装修工程设计方向与材料类型, 必须编制完整且合 理的设计方案。针对建筑装饰装修工程中较为困难的问题, 工程人员要与 不同的施工参与主体展开沟通交流, 完善装饰装修设计图纸, 且对装饰装 修设计方案实行反复修改, 由局部放大到整体, 确保整个施工流程一目了 然。不仅如此, 还要进一步优化施工组织设计, 参照招标方案进行预施工, 全面检查施工环节存在的细节问题, 提出切实可行的整改处理措施。

3. 3建立健全的施工管理体系

首先, 管理人员需建立完善的质量保障体系, 创建责任制度, 以增强施 工管理人员的责任感, 加强工程施工管理的规范性。其次, 建立科学完善的 工程建设诚信体系, 严肃抵制违法犯罪行为, 多次违规的企业和个人应列 入失信名单。再次, 建立工程质量保证金机制, 依据建筑装饰工程建设的规 模和形制明确工程质量保证金扣用的比例, 严格管控责任管理机制。最后, 采购施工材料前, 需详细调查材料的性价比和生产商的信誉度, 选择优质 的供应商。

\section{4 利用智能技术, 落实动态管理}

建筑装饰装修分析中, 智能技术的科学合理应用有利于创建现代化分 析模型, 进而结合动态化数据信息制定科学有效的应对策略。施工管理人 员应当依据建筑装饰装修方案明确建筑装饰要素的分布。在建筑装饰装修 的过程中, 应用合适的颜色和样图等要素, 且利用智能化数据库的资源优 势, 工作人员需合理分析室内空间装修要素, 完善工程施工管理。建筑装饰
装修施工期间, 还要大力开发并利用智能技术, 全面提高建筑装饰装修 工程施工效率, 高度满足业主装修的各项要求, 制定科学的装饰装修结 构规划。

3. 5加强建筑装饰装修工程安全管理

在建筑装饰装修工程施工过程中, 应做好洞口临边修复美化处理, 注 重安全防护。通常情况下, 施工人员会采用红白相间的钢管加以处理, 并使 用钢板或铁皮完成安全防护。定期维护检查各类机械设备, 优化机械设备 性能, 在此基础上, 结合各类机械设备性能特征, 优化设备组合形式。再者, 加强建筑装饰装修工程防火安全管理, 建立完善的消防应急处置体系, 确 保安全生产与安全检查的协同运转。制定并推行三级防火制度, 积极做好 建筑装饰装修工程安全管理工作。

另外, 工程人员还需注重对施工现场环境的保护, 严格控制扬尘污染、 噪音污染、光污染与水污染。例如, 选择适宜的照明强度进行施工; 加大 对隔离、防漏、清洁作业的投入力度; 控制有毒害性化学物质挥发量等。 最后, 严格控制建筑装饰装修工程的垃圾排放量, 减轻生态环境污染, 实现 生态效益的最大化。

3. 6 提高工作人员的综合素质

建筑装饰在工程施工中, 工作人员需要具备较高的综合素质, 从而切 实做好建筑装饰装修工程施工中的各项工作。建筑施工企业可参照我国法 律法规的要求, 高度落实施工技术培训工作, 积极宣传安全教育。一方面加 强工作人员的业务能力, 另一方面也可深化工作人员的安全意识, 有效落 实现场安全管理, 制定科学完善的管理机制, 保障工程的综合效益。

\section{5 结语}

综上所述, 建筑装饰装修工程管理期间, 务必严格遵照国家制定的规 范及要求, 减轻人为因素对工程施工管理的负面影响, 认真分析管理中的 问题, 以此制定完善的管理机制, 且注重智能技术的引入, 最终保障工程建 设的质量与安全, 推动工程的顺利完工。

\section{[参考文献]}

[1]黄伟.新时期装饰装修工程管理措施探究 [J].建材与装 饰,2019(10):196-197.

[2]谷春华.室内外装饰装修工程材料与工艺的创新[J].绿色环保建 材,2020(02):1.

[3] 颜芳. 新时期装饰装修工程管理措施探究 [J]. 建材与装 饰,2020(07):152-153. 